30. Mujsce DJ, Towfighi J, Stern D, Vannucci RC 1990 Mannitol therapy in perinatal hypoxic-ischemic brain damage in rats. Stroke 21:1210-1214

31. Hagberg H, Andersson P, Kjellmer I, Thiringer K, Thordstein M 1987 Extracellular overflow of flutamate, aspartate, GABA and taurine in the cortex and basal ganglia of fetal lambs during hypoxic-ischemia. Neurosci Lett $78: 311-317$

32. Andiné P, Sandberg M, Bảgenholm R, Lehmann A, Hagberg H 1991 Intraand extracellular changes of amino acids in the cerebral cortex of the neonatal rat during hypoxic-ischemia. Dev Brain Res 4:115-120

33. Silverstein FS, Naik B, Simpson J 1991 Hypoxia-ischemia stimulates hippocampal glutamate efflux in perinatal rat brain: an in vivo microdialysis study. Pediatr Res 30:587-590
34. McDonald JW, Johnston MV 1990 Physiological and pathophysiological roles of excitatory amino acids during central nervous system development. Brain Res Rev 15:41-70

35. Dumuis A, Sebben M, Haynes L, Pin J-P, Bockaert J 1988 NMDA receptors activate the arachidonic acid cascade system in striatal neurons. Nature 336:68-70

36. Pellegrini-Giampietro DE, Cherici G, Alesiani M, Carla V, Moroni F 1988 Excitatory amino acid release from rat hippocampal slices as a consequence of free-radical formation. J Neurochem 51:1960-1963

37. Kjellmer I, Andiné P, Hagberg H, Thiringer K 1989 Extracellular increase of hypoxanthine and xanthine in the cortex and basal ganglia of fetal lambs during hypoxia-ischemia. Brain Res 478:241-247

\title{
Announcement
}

\section{Second Announcement and Call for Papers}

The World Congress on Rett Syndrome will be held in Antwerp, Belgium from October 8 to October 10, 1993. The Congress is organized by the Belgium Rett Syndrome Association under the gracious patronage of her Majesty the Queen of Belgium. Sessions will be held on clinical aspects of Rett Syndrome (variability, variants, epilepsy, scoliosis, nutrition) and on basic research (genetics, neuropathology, neurometabolism). A poster session will be held on Saturday, October 9th. For further information, contact the Congress Secretary, Vanherck Peter, Lil 26, B-2450 Meerhout, Belgium; phone: 32-14-309494; fax: 32-14-303157. 